\title{
Genetic Variation in Cold Hardiness and Phenology Between and Within Turkish Red Pine (Pinus brutia Ten.) Populations: Implications for Seed Transfer
}

\author{
By G. E. KANDEMIR ${ }^{1), 2)}$, Z. KAYA ${ }^{\left.1),{ }^{*}\right)}$, F. TEMEL ${ }^{1), 3)}$ and S. ÖNDE ${ }^{1)}$
}

(Received 25 ${ }^{\text {th }}$ March 2008)

\begin{abstract}
Wind-pollinated seeds from 40 trees (half-sib families) were collected from each of six Turkish red pine (Pinus brutia Ten.) populations in southern Turkey. Two-year old seedlings were evaluated for growth, phenology and cold resistance in a common garden experiment established in Ankara, located outside the species' natural range. Each family was represented with a six-tree row plot within each of the three replications. The below freezing temperatures $\left(-15.2^{\circ} \mathrm{C}\right)$ observed in January and February of 2000 were sufficient to observe visually-assessable-cold damage to the seedlings. The populations significantly differed in all traits under investigation except for second flushing in 1999. Populations originating from more inland and higher elevation areas were more resistant to cold than coastal low elevation populations. Families within populations were significantly different as regards all traits except HT00. Family heritability for bud burst was 0.40 , and ranged from 0.12 to 0.37 for height, and from 0.20 to 0.23 for bud set.

Final height of cold damage prone seedlings was shorter than cold tolerant seedlings. Families with early bud-set, later bud-burst and shorter second flush shoots suffered less from cold damage. Considering the expected climate change in the eastern Mediterranean, there is a potential for using this species outside its natural range, especially in sites experiencing more continental climate since it will be possible to move the species $200-300 \mathrm{~m}$ in altitude and 2-3 degrees in latitude.
\end{abstract}

Key words: climate warming, cold damage, genetic variation, Pinus brutia, Turkish red pine.

\section{Introduction}

An increasing number of studies indicate that global warming affects wide range of species and ecosystems (WALther et al., 2002; PARMESAN and Yohe, 2003; Root et al., 2003; HAMANN and WANG, 2006). One of the major consequences of global warming in forestry is that the latitudinal and altitudinal shift in distribution ranges of forest tree species (e.g. KulLMAN, 2002). Therefore, climate change adaptation strategies should be viewed as part of the risk management component of a sustainable

\footnotetext{
1) Department of Biological Sciences, Middle East Technical University, Ankara, Turkey.

2) Present address: Forest Tree Seeds and Tree Breeding Research Directorate, Ankara, Turkey.

${ }^{3}$ ) Faculty of Forestry, Artvin Çoruh University, Artvin, Turkey.

*) Corresponding author: ZEKI KAYA. Address: Department of Biological Sciences, Middle East Technical University, 06531, Ankara, Turkey. Phone: +90-312-210-5177. Fax: +90-312-2107976. E-Mail: kayaz@metu.edu.tr
}

forest management plan (SPITTLEHOUSE, 2005). In reforestation, seed deployment policy will need to adapt to climate change by taking population responses to climate into consideration (MÁTYÁs 1996; WANG et al., 2006).

Like all living organisms, forest trees adapt to their local environments via natural selection over many generations. Geographic patterns of genetic variation for traits related to adaptation to climate (e.g. timing of initiation and cessation of growth, cold and drought hardiness and growth rates) are associated with climatic gradients in temperature and moisture (AITKEN and HANNERZ, 2001).

Turkish red pine (Pinus brutia Ten.) is the most widespread forest tree species and accounts for $15 \%$ of the total forest land (20.2 million ha) in Turkey. While its major distribution lies in the coastal regions of the Mediterranean and the Aegean Regions of Turkey, it can also be found in western Anatolia and central Black Sea Regions (Figure 1) (ARBEZ, 1974). Turkish red pine is considered to be a fast growing native conifer tree species with highly desirable wood characteristics and potential for industrial forestry, not only in Turkey, but also in Australia (SPENCER, 2001). Thus the species has been identified as one of the target species for intensive forestry and tree breeding projects in Turkey.

Although seed stand selections of Turkish red pine were initiated in 1960's, tree improvement studies have been accelerated after 1994 by preparation of "National Tree Breeding and Seed Production Programme for Turkey" (Koski and ANTOLA, 1993). Within this framework nine breeding zones were determined for Turkish red pine; selection of seed stands (82) and establishment of seed orchards (67) were completed. In addition, progeny trials were established in five breeding zones. A total of six seed transfer zones were delineated (ANONYMOUS, 2009).

The climate in Turkish red pine's natural range is predominantly mild with rare frost events. The mean annual temperature ranges between $12.5^{\circ} \mathrm{C}$ and $22.9^{\circ} \mathrm{C}$, mean January and July temperatures range from $2.7^{\circ} \mathrm{C}$ to $11.7^{\circ} \mathrm{C}$ and from $24.3^{\circ} \mathrm{C}$ to $30.8^{\circ} \mathrm{C}$, respectively (Records of General Directorate of Meteorology, Ministry of Environment and Forestry, 2007). According to the First National Communication on Climate Change of Republic of Turkey to United Nations Framework Convention on Climate Change (UNFCCC), by the end of this century average temperature will increase by $2-3{ }^{\circ} \mathrm{C}$ along with substantial changes in precipitation patterns (First National Communication on Climate 
Change of Republic of Turkey to UNFCCC, The Ministry of Forestry and Environment, Ankara, 276 p.). Thus, while some portions of Turkish red pine's natural range will become inhospitable for the species, opportunities may emerge for deploying Turkish red pine into areas that are formerly out of its natural range. Where there is lack of old provenance or genetic tests, as in the case of Turkish red pine, it is necessary to understand and evaluate the performance of Turkish red pine seed sources at off sites with early tests.

The climate in Ankara, located in central Turkey, is continental in character with dry summers and cold winters. With the changes in the climate, the region would become subject to re- and afforestation with Turkish red pine. Even with the increase in the temperatures through climate change, it is very likely to experience extreme weather conditions in the region. Ankara annually experiences, on average, 60 to 170 days with freezing temperatures. Thus, Ankara is a proper testing site for evaluating variation in Turkish red pine seed sources for their cold tolerance.

Objectives of the study were; (1) to investigate the genetic variation in cold hardiness, growth and phenology, (2) to determine relationship between cold hardiness and growth as well as between cold hardiness and phenology in Turkish red pine, and (3) to make some impli- cations on potential use of reproductive material outside species' natural range, based on genetic data obtained from this early test for cold hardiness, growth and phenology. For these purposes, seedlings of 240 open-pollinated families from six Turkish red pine populations in the species natural range grown in a nursery in Ankara were evaluated to meet the study objectives. To meet the objective 3 , the data from the test replicated with the same families in Antalya, evaluated by IşıK et al. (2002a), was also included in the current study.

\section{Materials and Methods}

\section{Plant material}

Six populations of Turkish red pine were sampled from southern Turkey. Three of these populations were over-exploited, while the other three were relatively undisturbed natural stands. Over-exploited populations have been highly degraded by roads, illegal tree harvesting, human-caused forest fires, and overgrazing (Yaylaalan, Çalkaya, Gölhisar). Natural populations are mostly inland populations, located at higher elevations where human caused disturbances were relatively low (Alanya, Fethiye, Çameli) (Table 1 and Figure 1).

Open-pollinated seeds (half-sib families) were collected from randomly selected 40 parent trees in each of the

Table 1. - Site description of the six Pinus brutia populations and the two test locations included in this study.

\begin{tabular}{|c|c|c|c|c|c|c|}
\hline & $\begin{array}{l}\text { Longitude } \\
\text { (E) }\end{array}$ & $\begin{array}{l}\text { Latitude } \\
\text { (N) }\end{array}$ & $\begin{array}{l}\text { Altitude } \\
\text { (m) }\end{array}$ & $\begin{array}{l}\text { Annual } \\
\text { Average } \\
\text { Precipitation } \\
(\mathrm{mm})\end{array}$ & $\begin{array}{l}\text { Average } \\
\text { Minimum } \\
\text { Temperature } \\
\text { Registered } \\
\text { in Fcbruary } \\
\left({ }^{\circ} \mathrm{C}\right)\end{array}$ & $\begin{array}{l}\text { Annual } \\
\text { Average } \\
\text { Tempcraturc } \\
\left({ }^{\circ} \mathrm{C}\right)\end{array}$ \\
\hline \multicolumn{7}{|c|}{ Populations* } \\
\hline 1-Alanya & $31^{\circ} 58^{\prime}$ & $36^{\circ} 36^{\prime}$ & 350 & 1103 & $5.00^{\mathrm{a}}$ & 18.8 \\
\hline 2- Yaylaalan & $31^{\circ} 30^{\prime}$ & $36^{\circ} 57^{\prime}$ & 500 & 1050 & $3.30^{\mathrm{a}}$ & 18.8 \\
\hline 3-Çalkaya & $30^{\circ} 50^{\circ}$ & $36^{\circ} 55^{\prime}$ & 50 & 1060 & $6.70^{\mathrm{a}}$ & 18.6 \\
\hline 4-Fethiye & $29^{\circ} 28^{\prime}$ & $36^{\circ} 44^{\prime}$ & 800 & 993 & $0.80^{\mathrm{a}}$ & 18.8 \\
\hline 5- Gölhisar & $29^{\circ} 32^{\prime}$ & $37^{\circ} 40^{\prime}$ & 1100 & 634 & $-2.10^{\mathrm{a}}$ & 12.6 \\
\hline 6-Çameli & $29^{\circ} 07^{\circ}$ & $37^{\circ} 06^{\prime}$ & 800 & 1222 & $0.20^{\mathrm{a}}$ & 18.0 \\
\hline \multicolumn{7}{|c|}{ Test Locations } \\
\hline Ankara & $32^{\circ} 53^{\prime}$ & $39^{\circ} 57^{\prime}$ & 780 & 378 & $\begin{array}{l}-2,2^{b} \\
\left(1.9^{c}\right)\end{array}$ & 11.7 \\
\hline Antalya & $36^{\circ} 54^{\prime}$ & $30^{\circ} 44^{\prime}$ & 52 & 783 & $\begin{array}{c}5.7^{\mathrm{b}} \\
\left(9.9^{\mathrm{c}}\right)\end{array}$ & 18.7 \\
\hline
\end{tabular}

\footnotetext{
* Yaylaalan, Çalkaya and Gölhisar populations are overexploited while Alanya, Fethiye and Çameli populations are natural populations.

a these are the estimated temperatures of population localities from LocClim of FAO (Source: http://www.fao.org).

${ }^{\mathrm{b}}$ Average minimum temperature in February from 1975-2008,

c Average temperature in February from 1975-2008 (Source: http://www.dmi.gov.tr/ veridegerlendirme/il-ve-ilceler-istatistik.asp $\underline{x}$.
} 


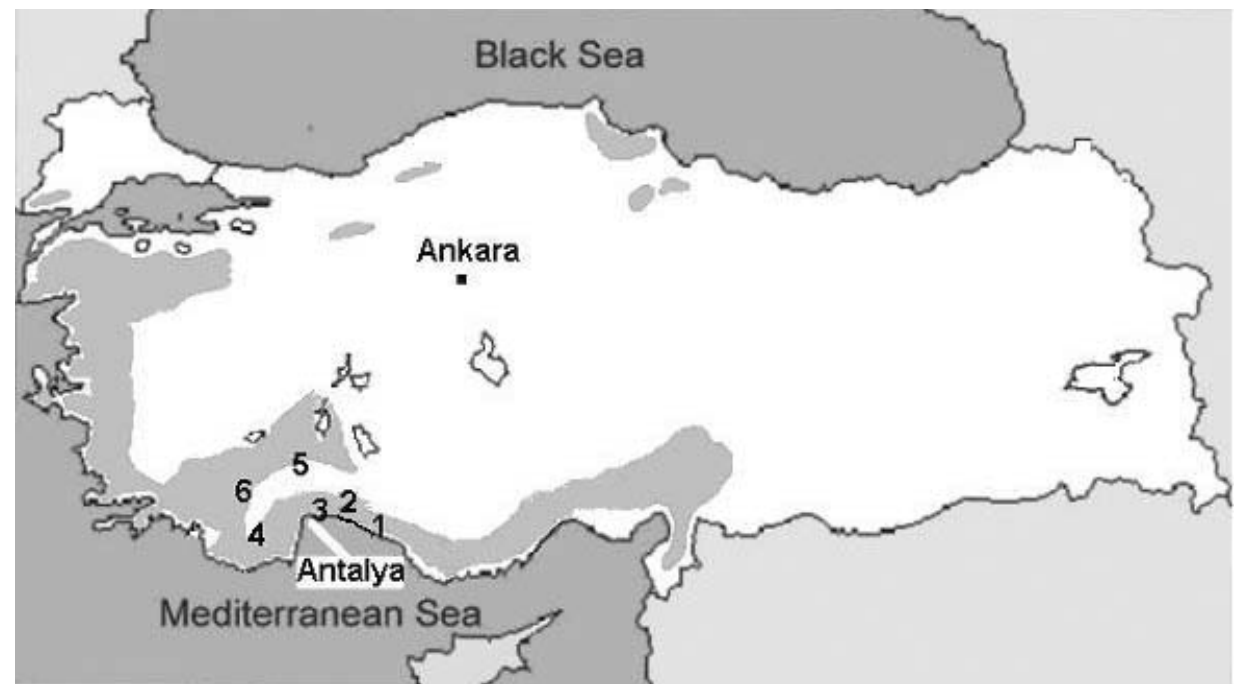

Figure 1. - Distribution of Pinus brutia in Turkey (shaded areas) and locations of studied populations (1 to 6) and the nursery (Ankara). IşıK et al.'s (2002) experiment was established in Antalya. Also see table 1.

six populations (240 families in total). In selecting parent trees, following sampling restrictions were applied: (1) parent trees had to be separated by at least $100 \mathrm{~m}$ within each population, (2) elevational range of the parent trees had to be no greater than 300 meters within any one population, and (3) cones had to be collected from the upper one-third of the crown of mother trees in order to minimize inbred and close bred seeds. Seeds were extracted from cones in open air and stored at $4^{\circ} \mathrm{C}$ until they were used.

\section{Description of tests}

In the spring of 1998 , seeds of the 240 families were planted as six-seedling row plots in each of three replications where families were randomly allocated to plot locations in each replication at a nursery in Ankara, Turkey. IşıK et al. (2002a) conducted a common garden study using the same experimental design and the same Turkish red pine families included in this study to investigate the effects of water stress on adaptive traits at a nursery in Antalya (Table 1 and Figure 1). Antalya is within the natural range of Turkish red pine in Turkey. Thus, this study presented an opportunity to compare relative performances of the Turkish red pine families tested both in and out of species' natural range. The suitable trait for comparison between the two studies was seedling height at the end of the second growing season (1999 for the current study and 2000 for IşıK et al. (2002a)). In each study, seedlings were 19-month-old from seed germination at the time of height measurement. Mean seedling heights for each population were compared.

\section{Measured traits and measurement methods}

Seedling height, as the distance from the cotyledon scar to base of terminal bud, was measured at the end of each growing season from 1998 to 2000. Length of shoot resulting from second flushing was measured as the distance from the second flushing point to the base of ter- minal bud in 2-11 August 1999. Bud-set was recorded at the end of growing seasons of 1999 (3-5 September) and 2000 (9-16 August), as the presence or absence of brown bud scales on the terminal bud. Bud-burst was recorded in the spring of 2000 (12-18 April), as the presence or absence of the new needles (Table 2). In assessing budset and bud-burst, assessment of a given replication was completed within a single day.

The winter of 1999 was a mild one. However, the freezing temperatures experienced in January and February of 2000 provided the ideal frost treatment to plant material. The minimum temperatures observed in January and February of 2000 were $-15.2{ }^{\circ} \mathrm{C}$ and $-11.2{ }^{\circ} \mathrm{C}$, and mean monthly temperatures were $-3.6^{\circ} \mathrm{C}$ and $-1.1^{\circ} \mathrm{C}$, in the respective months. The level of cold damage to seedlings was visually assessed on a scale from 0 to 5 in April 2000 based on the proportion of damaged needles (Table 2).

\section{Data analyses}

Objective 1: Investigating genetic variation in growth, phenology and cold hardiness. Data analyses were conducted using the SAS statistical package (SAS, 1990). All traits were subjected to Analysis of Variances (ANOVA). The linear ANOVA model for the entire data set was as follows:

$$
Z_{i j k}=\mu+B_{k}+P_{j}+F(P)_{i(j)}+e_{i j k}
$$

where $\mu$ is the experimental mean, $z_{i j k}$ is the mean performance of the $i^{\text {th }}$ family in the $j^{\text {th }}$ population in the $k^{\text {th }}$ replication; $B_{k}$ is the effect of $k^{\text {th }}$ replication; $P_{j}$ is the fixed effect of $j^{\text {th }}$ population; and $F(P)_{i(j)}$ is the random effect of $i^{\text {th }}$ family within population $j ; e_{i j k}$ is the experimental error.

ANOVA was conducted using PROC GLM (Generalized Linear Models) of the SAS statistical package to test significance of family differences (Type III sums of squares). Variance components were then estimated 
Table 2. - Measured seedling characteristics and measurement methods.

\begin{tabular}{|c|c|c|}
\hline Variable Names & Description & Dimensions and Units \\
\hline $\begin{array}{l}\text { HT98, HT99 and } \\
\text { HT00 }\end{array}$ & $\begin{array}{l}\text { Seedling height at the end of each } \\
\text { growing season from } 1998 \text { to } \\
2000 \text {. }\end{array}$ & $\mathrm{mm}$ \\
\hline SF99 & Length of second flush in 1999. & $\mathrm{~mm}$ \\
\hline BS99 and BS00 & $\begin{array}{l}\text { Bud-set in } 1999 \text { ( } 3-5 \text { September) } \\
\text { and } 2000 \text { (9-16 August). }\end{array}$ & $\begin{array}{l}0=\text { bud set } \\
1=\text { no bud set }\end{array}$ \\
\hline BB00 & Bud burst in 2000 (12-18 April). & $\begin{array}{l}0=\text { bud burst } \\
1=\text { no bud burst }\end{array}$ \\
\hline $\mathrm{CD} 00$ & $\begin{array}{l}\text { Cold damage in winter of } 1999 \text { - } \\
2000 .\end{array}$ & $\begin{array}{l}0=\text { no damage, } 1=\text { up to } 20 \% \\
\text { of the needles damaged, } 2=\text { up } \\
\text { to } 40 \% \text { of the needles damaged, } \\
3=\text { up to } 60 \% \text { of the needles } \\
\text { damaged, } 4=\text { up to } 80 \% \text { of } \\
\text { needle damaged, } 5=\text { dead. }\end{array}$ \\
\hline
\end{tabular}

using the REML (Restricted Maximum Likelihood) method of the VARCOMP procedure. REML estimates of variance components are considered more reliable than ANOVA estimates when imbalance exists in data (SwALLOW and MonAhan, 1984; SEARle et al., 1992; White, 1996). All tests of significance were conducted at 0.05 probability level.

Family heritabilities $\left(h_{f}^{2}\right)$ were estimated following FALCONER and MACKAY (1996) as;

$$
h_{f}^{2}=\frac{\sigma_{f}^{2}}{\frac{\sigma_{e}^{2}}{r}+\sigma_{f}^{2}}
$$

where $\sigma_{f}^{2}$ is the family component of total variance, $\sigma_{e}^{2}$ is the error variance, and $r$ is the mean number of replications provided by the GLM procedure.

Objective 2: Examining relationship between cold hardiness and growth and phenology. Phenotypic and genetic correlations were estimated to investigate the relationships among the traits. Phenotypic correlation $\left(r_{p(x, y)}\right)$ between traits $x$ and $y$ was estimated as (KAYA and TEMERIT, 1994);

$$
r_{p(x, y)}=\frac{M C P_{f(x, y)}}{M S_{f(x)} M S_{f(y)}}
$$

where $M C P_{f(x, y)}$, is the family-mean cross products for traits $x$ and $y, M S_{f}$ is the family-mean squares for respective traits $x$ and $y$.

Genetic correlation $\left(r_{g(x, y)}\right)$ between traits $x$ and $y$ was estimated as (FALCONER and MACKAY, 1996);

$$
r_{g(x, y)}=\frac{\operatorname{COV}_{f}(x, y)}{\sqrt{\sigma_{f(x)}^{2} \sigma_{f(y)}^{2}}}
$$

where $\operatorname{COV}_{f}(x, y)$ is the family-covariance between traits $x$ and $y$, estimated as

$$
\operatorname{Cov}(x, y)=\frac{\sigma_{f(x+y)}^{2}-\sigma_{f(x)}^{2}-\sigma_{f(y)}^{2}}{2},
$$

and $\sigma_{f}^{2}$ is the respective family variance component for traits $x$ and $y$ (STONECYPHER, 1992).
Standard errors of genetic correlations were calculated according to FALCONER and MACKAY (1996):

$$
\sigma_{\left(r_{g}\right)}=1-r_{g}^{2} \sqrt{\left[\frac{\sigma_{\left(h_{x}^{2}\right)} \sigma_{\left(h_{y}^{2}\right)}}{h_{x}^{2} h_{y}^{2}}\right]}
$$

Where $\sigma\left({ }_{r_{g}}\right)$, is the standard error of genetic correlation between traits $x$ and $y, \sigma_{\left(h_{x}^{2}\right)}$ is the heritability for trait $x, \sigma_{\left(h_{y}^{2}\right)}$ is the standard error of heritability for trait $y, h_{x}^{2}$ is the standard error of heritability for trait $x, h^{2}$ is the heritability for trait $y$ and before $h_{y}^{2}$.

Objective 3: To make some implications on potential use of reproductive material outside species' natural range, based on genetic data obtained from this early test for cold hardiness, growth and phenology. IşıK et al. (2002a) conducted a common garden study using the same Turkish red pine families included in this study to investigate the effects of water stress on adaptive traits at a nursery in Antalya. Antalya is within the natural range of Turkish red pine in Turkey. Thus, this study presented an opportunity to compare relative performances of the Turkish red pine families tested both within and outside species' natural range. The suitable trait for comparison between the two tests was seedling height at the end of the second growing season (1999 for the current study and 2000 for IşIK et al. (2002)). In each study seedlings were 19-month-old from seed germination at the time of height measurement. The performances of populations in each test site were compared by estimating population mean deviations from respective test site-means for height and plotted comparatively in Figure 2.

\section{Results}

Objective 1. Significant differences were observed at population $(P \leq 0.01$ for HT98, HT99, HT00, BS99, BB00, BS00 and CD00) and family levels $(P \leq 0.01$ for HT98, HT99, SF99, BS99, BB00, BS00 and CD00), except for SF99 and HT00 where populations and families, respectively, did not differ significantly. The propor- 


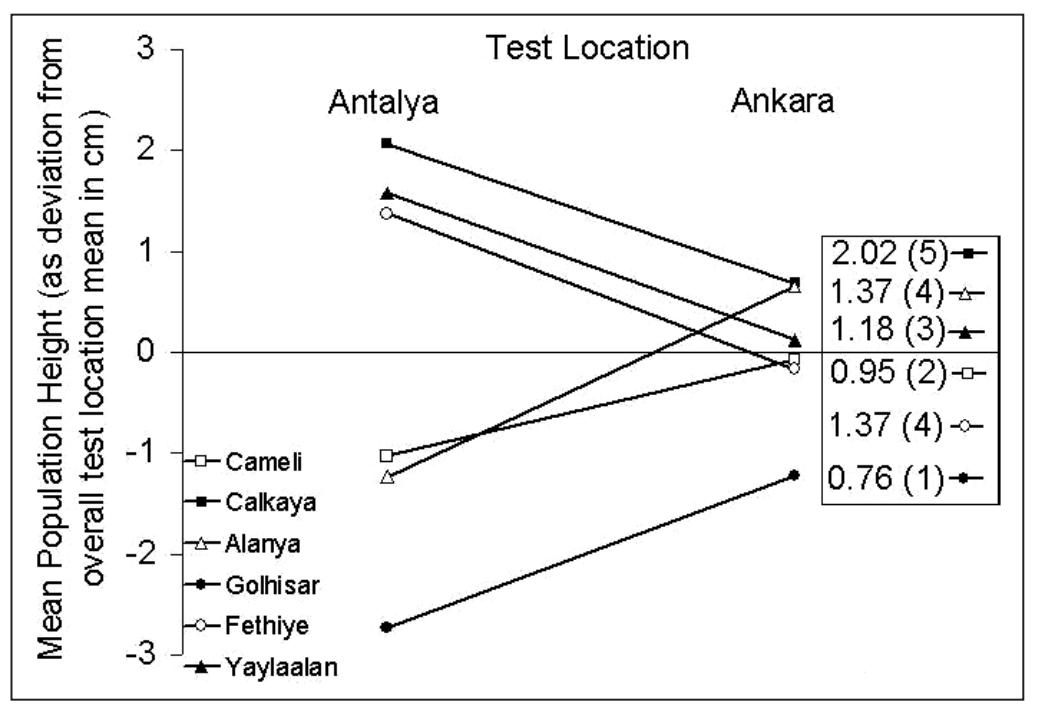

Figure 2. - Relative height growth performances of the six Pinus brutia populations in Antalya (IşıK et al., 2002) and in Ankara. Values given in the box on the right side of the figure are mean cold damage scores (CD00, see Table 2 ) in Ankara with their ranks ( $1=$ most cold resistant, $5=$ most cold sensitive, Fethiye and Alanya tied for the $4^{\text {th }}$ place) in parentheses.

tions of total variation due to families and populations were similar for HT98, HT00, and BS99 traits. However, the family-proportion of total variance was greater than populations for HT99, SF99 and BB00 and smaller for BS00 and CD00. Population differences were especially pronounced for winter frost damages. Family mean heritabilities ranged from 0.12 to 0.40 (Table 3).

The most cold sensitive population was the Çalkaya population (mean CD00 = 2.02). The two populations from more inland areas (Gölhisar and Çameli) were the most tolerant to cold than coastal populations (Alanya, Çalkaya, and Yaylaalan) (Table 4). The percent of seedlings scored with cold damage scores of 4 and 5 in each population varied from $0.54 \%$ seedlings from Gölhisar to $10 \%$ of seedlings from Çalkaya. The percent of seedlings with high cold damages were $1.08 \%$ in Çameli, $1.53 \%$ in Yaylaalan, $1.58 \%$ in Fethiye and $1.89 \%$ in Alanya. Off the seedlings with scores of 4 and 5 cold damages, $2.88 \%$ seedlings from Çalkaya, $40 \%$ from Fethiye , 55.6\% from Yaylaalan, 63.6\% from Alanya, $66.6 \%$ from Gölhisar and Çameli were recovered by reflushes of mostly lateral buds.

Objective 2. In general, magnitude and sign of genetic correlations followed the pattern of phenotypic correlations. Thus, here on, only genetic correlations will be reported unless otherwise noted. HT98, HT99 and HT00 were highly correlated (Table 5). HT98, HT99 and HT00 were moderately and positively correlated with second flushing in 1999 (SF99) ( $r_{g}$ range from 0.57 to 0.81). The genetic correlations between HT00 and BS00 could not be estimated due to lack of significant family variance in HT00, but a positive phenotypic correlation between HT00 and BS00 of 0.35 was significant at $P \leq 0.05$. Although height growth tended to correlate moderately with early bud-burst and late bud set, the standard errors of estimates were high (Table 5). Nevertheless, the moderate correlations were evident from the magni- tude of estimated phenotypic correlations between height growth and phenological traits.

The correlation of CD00 with HT98 $\left(r_{g}=0.78\right)$ and HT99 $\left(r_{g}=0.29\right)$ was positive, while it could not be estimated between HT00 and CD00 though there was strong negative phenotypic correlation between these two traits $\left(r_{p}=-0.68\right)$, (Table 5).

Genetic correlations between cold damage (CD00) with bud phenology traits (BS99, BB00 and BS00) indicated that seedlings with early bud-set and late budburst were less damaged by frost. Cold damage assessment revealed that the seedlings with longer shoot growth as a result of second flushing (SF99) suffered more from the cold (CD00 $\left.r_{p}=0.30\right)$. There was also moderately strong negative genetic correlation between BS00 and BB00 $\left(r_{g}=-0.36\right)$, indicating that families with early bud burst were that ones with late bud set in the growing season of 2000 (Table 5).

Objective 3. While the mean second year seedling heights of populations in Ankara test (outside natural range of Turkish red pine, present study) were 78 to $89 \%$ of mean seedling heights attained in Antalya test (IşIK et al., 2002a). In general, ranking of the populations were similar at both test sites with respect to seedling height, Çalkaya population being the tallest and Gölhisar population being the shortest in both test locations. Among the populations, Alanya population, which is with observed high heterozygosity, high polymorphic loci and almost no inbreeding (LISE et al., 2008), seems to have more sensitive to environmental changes with respect to height growth while the other populations were with more stable performances (Figure 2).

Average seedling heights for populations originating from coastal areas (low elevation, i.e., Alanya, Yaylaalan, Çalkaya) were greater than that of inland populations (high elevation, i.e., Fethiye, Gölhisar, Çameli), 
Table 3. - The results of ANOVA (analysis of variance); mean squares (MS), proportion of variances (VC, in \%) and family mean heritabilities $\left(h_{f}^{2}\right)$ for the traits included in the study. See table 2 for trait descriptions.

\begin{tabular}{|c|c|c|c|c|c|c|c|c|c|}
\hline \multirow[t]{2}{*}{ Traits } & \multicolumn{2}{|c|}{$\begin{array}{l}\text { Replications } \\
\quad\left(\mathrm{df}^{\mathrm{l}}=2\right)\end{array}$} & \multicolumn{2}{|c|}{$\begin{array}{l}\text { Populations } \\
\quad(\mathrm{df}=5)\end{array}$} & \multicolumn{2}{|c|}{$\begin{array}{l}\text { Families } \\
(\mathrm{df}=234)\end{array}$} & \multicolumn{2}{|c|}{$\begin{array}{c}\text { Error } \\
(\mathrm{df}=433)\end{array}$} & \multirow{2}{*}{$h_{f}^{2}$} \\
\hline & MS & $\mathrm{VC}$ & MS & $\mathrm{VC}$ & MS & $\mathrm{VC}$ & MS & $\mathrm{VC}$ & \\
\hline HT98 & 2445.12 & 13 & $1331.73^{\text {qF }}$ & 13 & $82.66^{* *}$ & 12 & 52.57 & 62 & 0.37 \\
\hline HT99 & 52434.32 & 21 & $6604.13^{* *}$ & 4 & $975.02^{* *}$ & 8 & 711.16 & 67 & 0.26 \\
\hline SF99 & 1944.95 & 7 & $31.74^{\mathrm{NS}}$ & 0 & $119.00^{* *}$ & 7 & 90.49 & 86 & 0.20 \\
\hline HT00 & 327697.57 & 28 & $24504.25^{* * *}$ & 4 & $3785.30^{\mathrm{NS}}$ & 3 & 3324.95 & 65 & 0.12 \\
\hline BS99 & 0.37 & 4 & $0.27^{* * *}$ & 8 & $0.032^{* *}$ & 8 & 0.026 & 80 & 0.23 \\
\hline $\mathrm{BB} 00$ & 0.24 & 1 & $0.32^{\text {** }}$ & 4 & $0.09^{* *}$ & 17 & 0.05 & 78 & 0.40 \\
\hline $\mathrm{BS} 00$ & $0.10^{\mathrm{NS}}$ & 0 & $2.09^{* *}$ & 21 & $0.09^{* *}$ & 6 & 0.07 & 73 & 0.20 \\
\hline CD00 & 1.33 & 1 & $18.60^{* *}$ & 38 & $0.32^{* *}$ & 6 & 0.26 & 55 & 0.25 \\
\hline
\end{tabular}

${ }^{1}$ Degrees of freedom. ${ }^{* *}$ Significant at $P \leq 0.01$; NS Non-significant at $P \geq 0.05$.

Table 4. - Population and overall means (standard error) for the traits included in the study. See table 2 for trait descriptions.

\begin{tabular}{lrrrrrrr}
\hline Traits & Alanya & Yaylaalan & Çalkaya & Fethiye & Gölhisar & Çameli & Overall \\
& & & & & & & \\
\hline HT98 & 52.49 & 48.79 & 51.67 & 53.04 & 43.95 & 47.18 & 49.60 \\
& $(0.83)$ & $(0.81)$ & $(0.82)$ & $(0.78)$ & $(0.75)$ & $(0.59)$ & $(0.39)$ \\
& & & & & & & \\
HT99 & 223.90 & 218.61 & 224.25 & 215.66 & 205.12 & 216.64 & 217.31 \\
& $(3.03)$ & $(2.77)$ & $(2.73)$ & $(3.12)$ & $(2.72)$ & $(2.68)$ & $(1.20)$ \\
& & & & & & & \\
SF99 & 7.82 & 7.84 & 7.11 & 7.56 & 6.57 & 8.53 & 7.57 \\
& $(0.95)$ & $(0.09)$ & $(0.91)$ & $(0.92)$ & $(0.89)$ & $(1.06)$ & $(0.40)$ \\
HT00 & 375.70 & 369.50 & 333.40 & 370.50 & 362.80 & 374.80 & 364.30 \\
& $(5.43)$ & $(5.36)$ & $(6.20)$ & $(6.06)$ & $(6.04)$ & $(6.16)$ & $(0.04)$ \\
BS99 & 0.93 & 0.95 & 0.81 & 0.86 & 0.89 & 0.94 & 0.89 \\
& $(0.02)$ & $(0.01)$ & $(0.02)$ & $(0.02)$ & $(0.02)$ & $(0.01)$ & $(0.01)$ \\
BB00 & 0.24 & 0.20 & 0.30 & 0.35 & 0.29 & 0.22 & 0.27 \\
& $(0.03)$ & $(0.02)$ & $(0.02)$ & $(0.03)$ & $(0.03)$ & $(0.02)$ & $(0.01)$ \\
BS00 & 0.73 & 0.70 & 0.39 & 0.58 & 0.77 & 0.77 & 0.66 \\
& $(0.03)$ & $(0.03)$ & $(0.03)$ & $(0.03)$ & $(0.02)$ & $(0.02)$ & $(0.01)$ \\
& & & & & & & \\
CD00 & 1.37 & 1.18 & 2.02 & 1.37 & 0.76 & 0.95 & 1.28 \\
& $(0.05)$ & $(0.05)$ & $(0.07)$ & $(0.04)$ & $(0.04)$ & $(0.04)$ & $(0.01)$ \\
\hline & & & & & & &
\end{tabular}

both in Ankara (222.25 mm vs. $212.47 \mathrm{~mm}$ ) and in Antalya (272.33 mm vs. $256.33 \mathrm{~mm}$ ). Seedlings originating from inland populations were slightly better in repeating their Antalya height growth performances in Ankara than those originating from coastal populations ( $83 \%$ vs. $82 \%)$. While at both test locations seedlings from coastal populations were taller than those from inland populations, seedlings from inland populations attained higher proportions of height compared to coastal populations in Ankara (96\%) than they did in Antalya (94\%) test site (Figure 2).

\section{Discussion}

The results revealed that there is a considerable amount of genetic variation among populations as well as families within populations in phenology and cold hardiness. Similar results have been reported in previ- 
Table 5. - Phenotypic (above diagonal) and genetic (below diagonal) correlations (standard errors are given in parentheses) among traits.

\begin{tabular}{ccccccccc}
\hline & & & & & & & & \\
& HT98 & HT99 & HT00 & SF99 & BS99 & BB00 & BS00 & CD00 \\
\hline HT98 & -- & 0.55 & 0.39 & 0.34 & 0.22 & -0.26 & 0.15 & 0.29 \\
& & $(0.07)$ & $(0.08)$ & $(0.08)$ & $(0.09)$ & $(0.08)$ & $(0.09)$ & $(0.09)$ \\
HT99 & 0.74 & -- & 0.71 & 0.58 & 0.31 & -0.37 & -0.27 & 0.24 \\
& $(0.15)$ & & $(0.05)$ & $(0.06)$ & $(0.09)$ & $(0.08)$ & $(0.09)$ & $(0.09)$ \\
HT00 & 0.67 & 0.82 & -- & 0.49 & 0.24 & -0.21 & 0.35 & -0.68 \\
& $(0.31)$ & $(0.19)$ & & $(0.07)$ & $(0.10)$ & $(0.09)$ & $(0.10)$ & $(0.11)$ \\
SF99 & 0.74 & 0.81 & 0.57 & -- & 0.23 & -0.27 & 0.12 & 0.30 \\
& $(0.22)$ & $(0.15)$ & $(0.32)$ & & $(0.09)$ & $(0.08)$ & $(0.10)$ & $(0.09)$ \\
BS99 & 0.35 & 0.16 & 0.36 & 0.61 & -- & -0.61 & 0.29 & 0.20 \\
& $(0.27)$ & $(0.32)$ & $(0.48)$ & $(0.35)$ & & $(0.06)$ & $(0.09)$ & $(0.10)$ \\
BB00 & -0.35 & -0.37 & -0.38 & -0.51 & -0.79 & -- & -0.25 & -0.30 \\
& $(0.18)$ & $(0.19)$ & $(0.33)$ & $(0.22)$ & $(0.17)$ & & $(0.09)$ & $(0.09)$ \\
BS00 & 0.46 & -0.44 & NE* & -0.02 & 0.55 & -0.52 & -- & -0.20 \\
& $(0.28)$ & $(0.30)$ & & $(0.35)$ & $(0.36)$ & $(0.26)$ & & $(0.10)$ \\
CD00 & 0.78 & 0.29 & NE & NE & -0.90 & -0.77 & -0.38 &.- \\
& $(0.29)$ & $(0.31)$ & & & $(0.47)$ & $(0.28)$ & $(0.38)$ & \\
\hline
\end{tabular}

* Not estimable. Phenotypic correlations, greater than \pm 0.14 are statistically significant at $P \leq 0.05$.

ous studies dealing with different populations of this species (IşıK, 1986; KAYA and IşIK, 1997) as well as other conifer species in the region (KAYA and TEMERIT, 1994; VELiOĞLU et al., 2000). Significant variation among populations observed in this study is not surprising because widespread species tend to have greater variation than that of species with limited distribution (LEDIG, 1987).

In general, family contribution to the total variance is high in most traits, but it appears that larger proportion of total variance resides among populations for CD00, rather than families within populations. Among the six populations included in this study, Calkaya (a low elevation population and close to the Mediterranean Sea) was the most cold-sensitive and Gölhisar (a high elevation population and located in inland) population was the most cold-hardy. In Gölhisar population, up to $66 \%$ of seedlings with severe cold-damages were able to recover in the following growing season while the recovery rate was very low in Çalkaya population (about $3 \%$ ). Interestingly, including coastal-low elevation populations, the recovery rate of seedlings in other populations was greater than $40 \%$. This could be explained with nature of shoot growth pattern of this population which is characteristics with relatively high height growth and long growing season since the frequency of families with early budburst and late bud set in year 2000 were high in this population. In fact, about $61 \%$ of seedlings from this population were still growing in September of 2000 while this ratio was ranging from $23 \%$ in inland populations to $42 \%$ in Fethiye. Furthermore, an overexploitated nature of population with a low buffering capacity (an isolated and mixed stand with low genetic diversity (Lise et al., 2008)) may also contribute to low recovery rate from cold damages.
Reliability of visual cold damage assessment was tested with measurement of variable fluorescence as described in BINDER and FIELDER (1996) and FISKER et al. (1995) on the studied seedlings after exposing to low temperature of winter 2000 (KANDEMIR, 2002). This visual cold damage assessment revealed the existence of considerable amount of genetic variation among population and families within populations of Turkish red pine for CD00. Especially the population component of variation was high, suggesting that selection at the population level could be practiced to improve cold hardiness of Turkish red pine material for inland plantation sites. For example, with regard to minimum average February temperature of Ankara test site and location of Gölhisar population appear to be well matched (See Table 1). Also, the seedlings from this population were the least affected with winter low temperature of Ankara. Climatic extrapolation of populations from entire species range could be matched with the plantation sites to improve seed transfers to outside natural range of species. Once the most cold-hardy populations are determined, the most cold-hardy families then could be selected from these populations to further improve cold hardiness. While the families within a particular population are selected, special emphases should be given to the relationship between growth traits and phenological traits as well as among phenological traits themselves. For instance, the existence of negative genetic correlation in timing bud burst and bud set would be useful to make selection of families for early bud- setting, late bud bursting and less or no second flush so early and late frost damages could be minimized. However, this trade off could be reduced if high elevation and inland populations are selected as seed sources.

A recent report on potential impacts of climate change on agriculture and forestry in Europe suggests that adaptive management strategies should be developed to alleviate the negative impacts of global warming (i.e., water shortage and extreme weather events) especially in the southern parts of the continent (MARACCHI et al., 2005). One such strategy in forest regeneration and afforestation is to determine new habitat patterns in the presence of climate warming and then, to deploy seedlings into new suitable environments (WANG et al., 2006). Climate warming is a reality more than a projection for Turkey and Turkish red pine forests will be the ones that are going to be most affected from it because of the area covered and its distribution. Climate change models regarding to Turkey suggest that an average of 2-3 degrees of temperature increase and $20 \%$ decrease in precipitation, especially central Turkey is expected to have milder climate than it is now. This indicates that Turkish red pine will certainly expand the current distribution range to 2-3 degrees north and $200-300 \mathrm{~m}$. higher elevations. The results in this study indicate that, when grown out of its natural range, Turkish red pine seedlings can attain to heights that are about $80 \%$ of when grown within the range. It should be pointed out that the data for this comparison were obtained from seedlings that are only at the end of their second growing season and it is not known whether this reduc- 
tion would be compensated or not by the end of the rotation age. It should also be remembered that selection of populations included in this study were not selected for the purpose of growth evaluation of Turkish red pine out of its range. Thus, it may be possible to attain similar growth rates by selecting more suitable seed sources.

Nevertheless, when there is lack of old tests for a given species, earl tests dealing with adaptive traits could be very useful (LAMBETH, 1980; LEINONEN and HÄNNINEN, 2002; ALDRETE et al., 2008; SogAARD et al., 2008). The provenance test (IşIK et al., 2002) of Pinus brutia, dealing with 50 provenance representing entire range of the species and tested in 26 sites including Ankara, is now at the age of 22 . The results of this test evaluated at at age of 10 , suggested that provenances originated higher altitudes $(\mathrm{r}=0.42)$ and latitudes $(\mathrm{r}=0.27)$ survived better in Ankara test sites, but there was no significant relationship between growth performances of provenances and latitudinal and altitudinal origins of them. In fact, it was shown for Pinus contorta that increase in growth is possible in an event of climate change, at least in some cases, when seed sources are deployed in further north than within the current breeding zones in British Columbia (WANG et al., 2006). Therefore, a more detailed evaluation of potential deployment areas for Turkish red pine seed sources is needed to develop new deployment strategies for the species under climate warming which is crucial for both the conservation of the species and its forestry.

\section{Conclusion}

The high elevation population, Gölhisar, was the most cold-tolerant, Çalkaya population with lowest altitude was the most cold-sensitive population, but in general populations located more inland and at higher elevations were more resistant to cold than populations originating from the coastal areas. Longer growth resulting from second flushing resulted in higher seedling heights, but also in higher cold damages. The families with later bud burst and earlier bud set had greater final seedling heights and suffered less from the cold while seedlings with longer growing season (late bud setting dates) length were severely damaged by cold.

Families originating from more inland and higher elevation populations were better in repeating their Antalya (within the natural range of Turkish red pine) growth performances in Ankara (out of the species range). In the presence of expected climate warming Turkish red pine can be moved northward without greatly sacrificing (at least in two-year old seedlings) its growth performance but long term assessment of this should be realized.

\section{Acknowledgements}

The open pollinated seeds for the study were collected by Southwest Anatolia Forest Research Institute (Antalya, Turkey). This study was carried out within the framework of the European Community International Cooperation with Developing Countries (INCODC) Research project on "Global, Physiological and Molecu- lar Responses to Climatic Stresses of Three Mediterranean Conifers" (FORADAPT \#IC18CT970200).

\section{References}

Aitken, S. N. and M. Hannerz (2001): Genecology and gene resource management strategies for conifer cold hardiness, pp. 23-53. In: Conifer cold hardiness, edited by F. S. Bigras and S. Culombo, Kluwer Academic Press, New York.

Aldrete, A., J. G. Mexal and K. E. Burr (2008): Seedling cold hardiness, bud set, and bud break in nine provenances of Pinus greggii Engelm. Forest Ecology and Management 255: 3672-3676.

ANONYMOUS (2009): 2008 Yılı Çalıșma Raporu, 2009 Yılı Çalışma Programı. Orman Ağaçları ve Tohumları Islah Araştırma Müdürlüğü, Sayı: 3, Ankara, Turkey. [Annual Report 2008, Work Program for 2009. Forest Tree Seeds and Tree Breeding Research Directorate, No: 3, Ankara, Turkey.]

ARBEZ, M. (1974): Distribution, ecology and variation of Pinus brutia in Turkey, pp. 21-33 in Forest Genetic Resources (No: 3), FAO, Rome/Italy.

BINDER, W. D. and P. FIELDER (1996): Chlorophyll fluorescence as an indicator of frost hardiness in white spruce seedlings from different latitudes. New Forests 11: 233-253.

FAlCONER, D. S. and T. F. C. MACKAY (1996): Introduction to quantitative genetics. Longman Group Ltd., London, UK.

FiskeR, S. E., R. Rose and D. L. HAAse (1995): Chlorophyll fluorescence as a measure of cold hardiness and freezing stress in 1+1 Douglas-fir seedlings. Forest Science 41: 564-575.

HAMANN, A. and T. WANG (2006): Potential effects of climate change on ecosystem and tree species distribution in British Columbia. Ecology 87: 2773-2786.

IşıK, F. (1986): Altitudinal variation in Pinus brutia Ten.: Seed and seedling characteristics. Silvae Genetica 35: 58-67.

IşıK, F., S. Keskin, R. SAbuncu, M. ŞAhin, M. N. BAŞ and Z. KAYA (2002): Effects of water stress on the adaptive traits of different Pinus brutia natural populations and families in a nursery trial, Technical Bulletin No: 15, Southwest Anatolia Forest Research Institute, Antalya, Turkey, $42 \mathrm{p}$.

KANDEMIR, G. E. (2002): Genetics and physiology of cold and drought resistance in Turkish red pine (Pinus brutia Ten.) populations from southern Turkey. PhD. Thesis, Middle East Technical University, Ankara, Turkey.

KAYA, Z. and A. TEMERIT (1994): Genetic structure of marginally located Pinus nigra var. pallasiana populations in Central Turkey. Silvae Genetica 43: 272-277.

KAYA, Z. and F. IşIK (1997): The pattern of genetic variation in shoot growth of Pinus brutia Ten. populations sampled from the Toros Mountains in Turkey. Silvae Genetica 46: 73-81.

Koski, V. and J. AnTola (1993): National Tree Breeding and Seed Production Program for Turkey 1994-2003, Enso Forest Development Oy. Ltd., Turkish-Finnish Forestry Project.

Kullman, L. (2002): Rapid recent range-margin rise of tree and shrub species in the Swedish Scandes. Journal of Ecology 90: 68-77.

LAMBETH, C. C. (1980): Juvenile-mature correlations in Pinaceae and implications for early selection. Forest Science 26: 571-580. 
LEDIG, F. T. (1987): Genetic structure and the conservation of California's endemic and near endemic conifers, pp. 587-594. In: Conservation and management of rare and endangered plants, edited by T. S. ELLIS, California Native Plant Society, Sacramento.

LEINONEN, I. and H. HÄNNINEN (2002): Adaptation of timing of bud burst of Norway spruce and boreal climates. Silva Fennica 36: 695-701.

MARACCHI, G., O. SiRotenko and M. Bindi (2005): Impacts of present and future climate variability on agriculture and forestry in the temperate regions: Europe. Climatic Change 70: 117-135.

MÁTYÁs, C. (1996): Climatic adaptation of trees: rediscovering provenance tests. Euphytica 92: 45-54.

PARMESAN, C. and G. YoHe (2003): A globally coherent fingerprint of climate change impacts across natural systems. Nature 421: 37-42.

Root, T. L., J. T. Price, K. R. Hall, S. H. Schneider, C. Rosenzweig and J. A. Pounds (2003): Fingerprints of global warming on wild animals and plants. Nature 421: 57-60.

SAS InstituTE INC. (1990): SAS/STAT(c) User's Guide, Version $6,4^{\text {th }}$ edition. Cary.

Searle, S. R., G. Casella and C. E. McCulloch (1992): Variance components. John Wiley \& Sons, New York.

SogaARD, G., O. Johnson, J. Nilsen and O. Junttila (2008): Climatic control of bud burst in young seedlings of nine provenances of Norway spruce. Tree Physiology 28: $311-320$.

Spencer, D. (2001): Conifers in the Dry Country: A report for the RIRDC/L\&W Australia/FWPRDC Joint Venture Agroforestry Program. CSIRO Forestry and Forest Products-Australia, RIRDC Publication No: 01/46, Australia, $60 \mathrm{p}$.
SpitTlehouse, D. L. (2005): Integrating climate change adaptation into forest management. Forestry Chronicle 81: 691-695.

STONECYPHeR, R. W. (1992): Computational methods, pp. 195-228. In: Handbook of quantitative forest genetics edited by L. Fins, S. T. Friedman and J. V. BRotschol, Kluwer Academic Publishers, Dordrecht, the Netherlands.

Swallow, W. H. and J. F. Monahan (1984): Monte Carlo comparison of ANOVA, MIVQUE, REML, and ML estimators of variance components. Technometrics 26: 47-57.

VelioĞLU, E., F. F. ÇiçEK, Z. KAYA and B. ÇENGEL (2000): Genetic variation in natural Kazdağı Fir (Abies equitrojani Aschers et. Sint.) populations sampled from Kazdağları, Technical Bulletin No: 3, Forest Tree Seeds and Tree Breeding Research Directorate, Ankara, Turkey, $31 \mathrm{p}$.

Walther, G. R., E. Post, P. Convey, A. Menzel, C. Parmesan, T. J. C. Beebee, J. M. Fromentin, O. Hoegh-GuldBERG and F. BAIRLEIN (2002): Ecological responses to recent climate change. Nature 416: 389-395.

Wang, T., A. Hamann, A. Yanchuk, G. A. O'Neill and S. N. AITKEN (2006): Use of response functions in selecting lodgepole pine populations for future climates. Global Change Biology 12: 2404-2416.

White, T. (1996): Genetic parameter estimates and breeding value predictions: issues and implications in tree improvement programs, pp. 110-117. In: Tree improvement for sustainable tropical forestry, edited by M. J. DieTERs, C. E. HARWOOD and S. U. WALKeR, Queensland Forestry Research Institute, Gympie.

\title{
Microsatellite Based Paternity Analysis in a Clonal Eucalyptus nitens Seed Orchard
}

\author{
By C. Grosser ${ }^{1), 2)}$, B. M. Potts ${ }^{1)}$ and R. E. Vaillancourt ${ }^{1), 3)}$
}

(Received $3^{\text {rd }}$ October 2008)

\begin{abstract}
Microsatellite markers were used to determine paternity in 473 open-pollinated progenies from a clonal Eucalyptus nitens seed orchard of 50 trees from 12 different genotypes. The outcrossing rate in this orchard was high, averaging 0.85 (weighted by capsule crop) but variable between trees (ranging from 0.6-1.0). Paternal contribution of each genotype to the open-pollinated seed crop was predicted by the size of the flower crop of

\footnotetext{
1) School of Plant Science and Cooperative Research Centre for Forestry, University of Tasmania, Private Bag 55, Hobart Tasmania 7001 Australia.

2) Forensic Science Service Tasmania. 20 St Johns Avenue, New Town Tasmania 7008 Australia.

3) Corresponding author: RENÉ E. VAILLANCOURT. E-Mail: R.Vaillancourt@utas.edu.au
}

each genotype $(\mathrm{r}=0.76)$, but not the number of ramets. While the detectable contamination in this orchard is relatively low $(4.5 \%)$, it is atypical when compared to other published estimates in eucalypt seed orchards suggesting that with suitable buffering low levels of contamination can be achieved.

Key words: Outcrossing rate; selfing; eucalypt genetics.

\section{Introduction}

Eucalyptus nitens (Deane \& Maiden) Maiden is a tall forest tree occurring naturally in disjunct populations on the southern side of the Great Dividing Range along the east coast of Australia (BROOKER and KLEINIG, 1983; HAMilton et al., 2008). This species has demonstrated a number of characteristics of value to the forest industry, 